\title{
THE ASSOCIATION BETWEEN DEPRESSION AND SELF- REPORTED SLEEP QUALITY AMONG HYPERTENSIVE PATIENTS IN A RURAL AREA OF CENTRAL SULAWESI
}

\author{
Ferdy Lainsamputty ${ }^{1}$, Indrawan Manitu ${ }^{1}$, Nur Abdillah ${ }^{2}$ \\ 1. Department of Nursing, Husada Mandiri Poso College of Health Sciences, \\ Jl. Pulau Kalimantan No. 29, Poso City, 94612, Indonesia \\ 2. Undergraduate Nursing Student, Husada Mandiri Poso College of Health Sciences, \\ Jl. Pulau Kalimantan No. 29, Poso City, 94612, Indonesia \\ E-mail: Lainsamputtyferdy@gmail.com
}

\begin{abstract}
Poor quality of sleep may increase burden of hypertensive patients and worsen quality of life. Recognition of individuals' sleep quality and its related factors might benefit the outcome of hypertension management. The purpose of this study was to investigate the association between depression and sleep quality among hypertensive patients in rural community. A cross-sectional, correlational study design was performed with 149 accidental samples at two public health care areas. Instruments included Depression Anxiety Stress Scale 42 and Pittsburgh Sleep Quality Index. Almost 78\% of participants experienced mild to moderate depression and $98.7 \%$ of poor sleepers were identified. Significant determinants of sleep quality were exercises and type 2 diabetes mellitus (DM). Depression was associated to sleep quality but was not identified as a determinant. This study suggests future interventions should be directed to increase regular exercises and controlling co-existing disease particularly type 2 DM should be developed to improve sleep quality.
\end{abstract}

Keywords: Depression, hypertension, sleep quality.

\begin{abstract}
Abstrak
Kualitas tidur yang buruk dapat memperberat beban pasien hipertensi dan menurunkan kualitas hidup. Mengidentifikasi kualitas tidur individu dan faktor-faktor yang terkait dengannya dapat membantu meningkatkan hasil dari manajemen penyakit hipertensi. Penelitian ini bertujuan untuk menginvestigasi asosiasi depresi dan kualitas tidur pada pasien hipertensi di daerah pedesaan. Desain penelitian menggunakan pendekatan potong lintang dan deskriptif korelasi dengan 149 sampel insidental pada wilayah kerja dua pusat kesehatan masyarakat. Kuesioner yang digunakan yaitu DASS-42 dan PSQI. Hampir 78\% partisipan menderita depresi ringan hingga sedang dan presentase kualitas tidur buruk sebanyak 98.7\%. Faktor determinan yang signifikan adalah olahraga dan DM tipe 2. Depresi berhubungan secara signifikan dengan kualitas tidur, tetapi tidak teridentifikasi sebagai faktor determinan. Penelitian ini merekomendasikan dilakukannya intervensi untuk meningkatkan kegiatan olahraga yang regular dan pengontrolan penyakit komorbiditas terutama DM tipe 2 untuk meningkatkan kualitas tidur.
\end{abstract}

Kata Kunci: Depresi, hipertensi, kualitas tidur.

\section{Introduction}

More than 1 billion people worldwide living with hypertension, predominantly in low- and middleincome countries (World Health Organization [WHO], 2019). This disease is a major cause of early death and as a risk factor for cardiovascular diseases such as chronic and coronary heart disease, stroke, and other complications including heart failure, visual and renal impairment, retinal bleeding, and peripheral vascular disease (WHO, 2011). Hypertension contributes a serious burden to the society and families (Zhang, Chen, Guan, \& Zhang, 2015). WHO (2019) mentioned that 1 over 4 men had hypertension which may threaten the family's financial condition if the disease is suffered by the head of the family. In the US, it costs $\$ 48.6$ billion each year. This amount includes the fee of 
health care services, drugs, and absence from work (Centers for Disease Control and Prevention, 2016). Ministry of Health Republic of Indonesia (2019) stated that the cost of hypertension has increased every year, from 2.8 trillion in 2014 up to 4.2 trillion rupiahs in 2018 .

There are many factors leading to hypertension and may have different characteristics among countries and even vary between rural and urban areas of the identical place (Rani, Mengi, Gupta, \& Sharma, 2015). For instances, patients with hypertension in the rural had lower detection and drugs use than their urban counterparts (Li et al., 2017). Approximately, more than two-thirds of Indonesian population have hypertension but they are unaware that suffering from this disease, $32.3 \%$ of them did not regularly take drugs and even worse $13.3 \%$ did not take medication. Some reasons for not taking medication are feeling healthy $(59.8 \%)$, irregular visits to health care center $(31.3 \%)$, taking traditional medicine $(14.5 \%)$, using other therapies $(12.5 \%)$, forget to take medication $(11.5 \%)$, cannot afford medicine $(8.1 \%)$, side effects of drugs $(4.5 \%)$, and hypertension drugs are not available in health care center (2\%) (Ministry of Health Republic of Indonesia, 2019)

The incidence of hypertension is higher among individuals with depressive symptoms $(\mathrm{Ma} \& \mathrm{Li}$, 2017). The prevalence of depression among hypertensive patients were from 26.6 to $41.7 \%$ (Ademola et al., 2019; Mahmood et al., 2017; Prathibha, Varghese, \& Jincy, 2017). Study showed that the prevalence of depression in elderly patients with hypertension living in rural areas was higher. Low educated and income, rarely hold medical insurance, poor health, and mental status were the causes of more prone to get depressed (Ma et al., 2015).

Hypertension and depression may create a vicious cycle (Xue et al., 2017). Despite its high existence and effect, depression is commonly not being noticed by healthcare professionals, and patients do not get proper treatment adequately, which may not only influence their quality of life (QoL), but also can affect the management of their disease (Meng, Chen, Yang, Zheng, \& Hui, 2012).

Patients with depression have a tendency to have sleep problems, characterized by difficulty falling/staying asleep and early awakening (Göder et al., 2016; Li, Wu, Gan, Qu, \& Lu, 2016). Sleep quality is considered lower in patients with hypertension (Xu et al., 2016). The prevalence ranges from 38.2 to $55.7 \%$ (Bruno et al., 2013; Hanus, Amboni, Rosa, Ceretta, \& Tuon, 2015). Appropriate sleep duration is necessary to maintain body function, lower the prevalence of obesity, metabolic syndrome, and to avoid adverse cardiovascular and cerebrovascular events (Chaput, McNeil, Despres, Bouchard, \& Tremblay, 2013; Kobayashi, Takahashi, Deshpande, Shimbo, \& Fukui, 2011). Apart from the duration, sleep quality is important aspect of sleep as well, especially its relationship with cardiovascular outcomes (Lo, Woo, Wong, \& Tam, 2018; Ma \& Li, 2017).

Research depicted the detail characteristics of patients with hypertension in relation to sleep quality in rural areas of Indonesia, particularly in Central Sulawesi is limited. This study was to address the prevalence of self-rated sleep quality and its related factors in people with hypertension including depression. The authors hypothesized the demographic variables, health-related characteristics, illness-related characteristics, and depression had association with nocturnal sleep quality. Understanding the prevalence of sleep problem and its determinants in hypertensive patients, however, is imperative to assist in the care of planning regarding this aspect in order to have a better outcome of hypertension management.

\section{Methods}

This study used descriptive correlational design with cross-sectional approach. Accidental samples were recruited from two public health care areas in Central Sulawesi, Indonesia. Data collection was started from July to August 2018. The inclusion criteria were patients with hypertension more than one year as diagnosed by physician based on International Classification of Diseases (ICD) Ninth Revision, adult (aged 18 years or older), can communicate in Bahasa Indonesia, and consent to join the study. Participants diagnosed with sleep disorder before their diagnoses of hypertension and pregnant women were excluded from this study. The G*Power software version 3.1.9.4 (Faul, Erdfelder, Buchner, \& Lang, 2009; Faul, Erdfelder, Lang, \& Buchner, 2007) was used to determine the sample size. By generating regression analysis test with a medium effect size of 0.15 (Cohen, 1988), an alpha level of 0.05 , a power of 0.8 , and 14 predictors, thus, the minimum sample of 135 subjects were needed to obtain enough power to detect significance variance contributed to the sleep quality outcome variable by the important correlates. However, the total number of subjects recruited in this study was 149 (response rate $=100 \%$ ).

Demographic variables, health-related characteristics, and illness-related characteristics were collected using a self-designed form. Demographic variables data included age, gender, 
occupation, religions, and tribes. Health-related characteristics included smoking, body mass index, exercise, and alcohol consumption. Illness-related characteristics included stages of hypertension, medications, duration of diagnosis, and comorbidity.

PSQI was utilized to measure sleep quality. There are 7 components: Subjective sleep quality, latency, duration, efficiency, disturbances, the use of sleep medications, and daytime dysfunction. Of 24 available questions in total, 19 self-rated questions will be used to obtain the global score, while 5 last questions rated by roommate/bed partner (if available) only as additional clinical information. Each of 7 component scores ranged from 0-3, thus, the lowest possible global sleep score is 0 , while the highest is 21. A global sleep score starting from 6-21 indicates poor sleep quality over the past month (Buysse, Reynolds, Monk, Berman, \& Kupfer, 1989). Psychometric analysis of the PSQI revealed good reliability (internal consistency) in hypertensive population, ranging from 0.76-0.80 (Hsu, Chen, Ho, \& Lin, 2018; Kara \& Tenekeci, 2017). Bahasa Indonesian version of PSQI has been used previously, with a Cronbach's alpha of 0.76 in heart failure patients (Lainsamputty \& Chen, 2018).

Depression was measured by the subscale of Depression Anxiety Stress Scale (DASS-42). This is a self-administered scale to assess individuals' symptoms of psychological states (depression, anxiety, and stress), which consists of 42 questions. Each subscale has 14 questions (depression: No. 3, $5,10,13,16,17,21,24,26,31,34,37,38,42$; anxiety: $2,4,7,9,15,19,20,23,25,28,30,36,40$, 41; stress: 1, 6, 8, 11, 12, 14, 18, 22, 27, 29, 32, 33, $35,39)$. All questions have 4 rating scales (answers), from 0 (did not apply to me at all to 3 (applied to me very much, or most of the time) and the range of possible scores (each scaled) is $0-42$. The normal range scores are 0-9 (depression), 0-7 (anxiety), and 0-14 (stress). Scores greater than these ranges indicate individuals' having psychological problem from mild to extreme level. This questionnaire is free to use, therefore, permission is not required. Moreover, no special skills are needed to administer it (Lovibond \& Lovibond, 1995). DASS-42 has been translated and validated into Bahasa Indonesia version by Damanik (2011) with the Cronbach's alpha of 0.95 . The internal consistency reliability for this scale and its short-form (DASS-21) in studies with hypertension as one of the major comorbidities were very impressive with Cronbach's alpha in the range of 0.84-0.86 (Nordin, Kaur, Soni, Por, \& Miranda, 2017) and 0.82-0.92 (Allabadi et al., 2019).

This study protocol was approved by the ethical committee of the public health care (No.:
440/08.08/SI/PKM-PD/VIII/2018). Eligible patients were referred from the physicians or nurses during patients' visit. The study aim and procedure were explained in detail. If willing to join, potential participants were contacted by researcher or research assistants individually. Confidentiality and privacy were assured and written informed consent was obtained before completing the questionnaires. Participants were free to withdraw if they felt uncomfortable or had any issues at any time. Data were collected via face-to-face structured interviews to complete questionnaires. The interview provided additional information for interpreting the data.

The data were analyzed using IBM SPSS version 23 for Windows (IBM Corp, Indonesia). The descriptive statistics included means, standard deviations, frequency distributions, percentages, and actual range were generated to describe all variables. The Mann-Whitney U-Test and Kruskal-Wallis HTest were used for statistical inference. Spearman correlation coefficients were employed to examine the correlation of sleep quality scores with the study variables. Hierarchical multiple regression analyses was conducted to identify the determinants of sleep quality. Prior to regression analysis, multicollinearity assumption was assessed by examining the variance inflation factor (VIF) and tolerance for all predictors involved in the model. Basically, tolerance is the reciprocal of VIF (Kellar $\&$ Kelvin, 2012). The values of tolerance lower than 0.1 were the indicators of possible multicollinearity (Polit \& Beck, 2012). The tests in all variables showed that the highest VIF was 1.04 and the lowest tolerance value was 0.96 indicating no multicollinearity assumption was violated. A level of alpha significance was set at 0.05 .

\section{Results \\ Participants' Characteristics}

Information regarding demographic variables, health-related characteristics, and illness-related characteristics are shown in Table 1. Mean participant age was 50.21 ( $\mathrm{SD}=10.26$ years); a majority were female $(62.4 \%)$, farmers $(65.8 \%)$, Muslim (64.4\%), and Bugisnese (36.2\%). Participants had a mean BMI of 25.25 ( $\mathrm{SD}=4.33$ $\mathrm{kg} / \mathrm{m}^{2}$ ), while mean duration of disease was 6.11 ( $\mathrm{SD}=4.38$ years). About $73.8 \%$ of participants were non-smokers and not regularly doing exercise $(85.2 \%)$. The majority $(86.6 \%)$ was in group of patients who did not drink alcohol. Group of stage I was more dominant $(70.5 \%)$, than those in stage II (29.5\%). Regarding daily antihypertension medication use, $92.6 \%$ of participants took calcium channel blockers (CCBs), meanwhile the rest used angiotensin-converting enzyme inhibitors (ACEIs). 
About $53 \%$ of participants had hyperuricemia and $4.6 \%$ suffered from type 2 DM.

Table 1. Demographic Variables, HealthRelated Characteristics, and Illness-Related Characteristics $(n=149)$

\begin{tabular}{|c|c|c|}
\hline Variables & $\begin{array}{c}\text { n }(\%) \text { or } \\
\text { Mean } \pm \text { SD }\end{array}$ & $\begin{array}{l}\text { Actual } \\
\text { Range }\end{array}$ \\
\hline Age in years & $50.21 \pm 10.26$ & $25-73$ \\
\hline \multicolumn{3}{|l|}{ Gender } \\
\hline Male & $56(37.6 \%)$ & \\
\hline Female & $93(62.4 \%)$ & \\
\hline \multicolumn{3}{|l|}{ Occupation } \\
\hline Farmer & $98(65.8 \%)$ & \\
\hline Entrepreneur & $44(29.5 \%)$ & \\
\hline Others & $7(4.7 \%)$ & \\
\hline \multicolumn{3}{|l|}{ Religions } \\
\hline Muslim & $96(64.4 \%)$ & \\
\hline Christian & $43(28.9 \%)$ & \\
\hline Hinduism & $10(6.7 \%)$ & \\
\hline \multicolumn{3}{|l|}{ Tribes } \\
\hline Bugisnese & $54(36.2 \%)$ & \\
\hline Javanese & $22(14.8 \%)$ & \\
\hline Lomboknese & $20(13.4 \%)$ & \\
\hline Pamonanese & $43(28.9 \%)$ & \\
\hline Balinese & $10(6.7 \%)$ & \\
\hline \multicolumn{3}{|l|}{ Smoking } \\
\hline Yes & $39(26.2 \%)$ & \\
\hline No & $110(73.8 \%)$ & \\
\hline BMI & $25.25 \pm 4.33$ & $17-38$ \\
\hline \multicolumn{3}{|l|}{ Exercises } \\
\hline Yes & $22(14.8 \%)$ & \\
\hline No & $127(85.2 \%)$ & \\
\hline \multicolumn{3}{|l|}{ Alcohol } \\
\hline Yes & $20(13.4 \%)$ & \\
\hline No & $129(86.6 \%)$ & \\
\hline \multicolumn{3}{|l|}{ Hypertension } \\
\hline \multicolumn{3}{|l|}{ Stages } \\
\hline I & $105(70.5 \%)$ & \\
\hline II & $44(29.5 \%)$ & \\
\hline \multicolumn{3}{|l|}{$\mathrm{CCBs}$} \\
\hline Yes & $138(92.6 \%)$ & \\
\hline No & $11(7.4 \%)$ & \\
\hline \multicolumn{3}{|l|}{ Duration of } \\
\hline Disease & $6.11 \pm 4.38$ & $2-26$ \\
\hline \multicolumn{3}{|l|}{ Hyperuricemia } \\
\hline Yes & $70(47 \%)$ & \\
\hline No & $79(53 \%)$ & \\
\hline \multicolumn{3}{|l|}{ Type 2 DM } \\
\hline Yes & $7(4.7 \%)$ & \\
\hline No & $142(95.3 \%)$ & \\
\hline
\end{tabular}

Note: BMI=Body Mass Index; $C C B s=$ Calcium Channel Blockers; DM=Diabetes Mellitus.

\section{Distributions of Depression Scores}

Depression scores ranged from 4 to 20 , with a mean of $11.55 \quad(\mathrm{SD}=2.75)$. Based on the scoring interpretation, $84(56.4 \%)$ of the participants had mild depression, $33(22.1 \%)$ were normal, and 32 (21.5\%) experienced moderate depression. No study participants had severe and extremely severe depression (see Table 2).

Table 2. Distributions of Depression scores and Categories $(n=149)$

\begin{tabular}{lccc}
\hline \multicolumn{1}{c}{ Variables } & $\begin{array}{c}\text { n }(\%) \text { or } \\
\text { Mean } \pm \text { SD }\end{array}$ & $\begin{array}{c}\text { Possible } \\
\text { Range }\end{array}$ & $\begin{array}{c}\text { Actual } \\
\text { Range }\end{array}$ \\
\hline Depression & $11.55 \pm 2.75$ & $0-42$ & $4-20$ \\
Normal & $33(22.1 \%)$ & & \\
Mild & $84(56.4 \%)$ & & \\
Moderate & $32(21.5 \%)$ & & \\
Severe & $0(0 \%)$ & & \\
Ext. Severe & $0(0 \%)$ & & \\
\hline Note: Ext.=Extremely.
\end{tabular}

\section{Self-Reported Sleep Quality Components and Global Scores}

The mean global PSQI score was $10.62(\mathrm{SD}=2.39$, with actual score range $=5-17)$. Using a cutoff point of 5 (Buysse et al., 1989), only 2 (1.3\%) participants were identified as good sleepers, while majority, 147 (98.7\%) participants had poor sleep quality. The mean sleep component scores ranged from 0.73 $(\mathrm{SD}=0.91)$ to $2(\mathrm{SD}=0.67)$, where habitual sleep efficiency was the lowest mean score and sleep latency as the highest (see Table 3).

Table 3. Sleep Quality Components Scores of the Study Participants $(n=149)$

\begin{tabular}{lccc}
\hline Variables & $\begin{array}{c}\text { n }(\%) \text { or } \\
\text { Mean } \pm \text { SD }\end{array}$ & $\begin{array}{c}\text { Possible } \\
\text { Range }\end{array}$ & $\begin{array}{c}\text { Actual } \\
\text { Range }\end{array}$ \\
\hline Global PSQI & $10.62 \pm 2.39$ & $0-21$ & $5-17$ \\
SL & $2.00 \pm 0.67$ & $0-3$ & $0-3$ \\
SDis & $1.93 \pm 0.26$ & $0-3$ & $1-2$ \\
SSQ & $1.86 \pm 0.57$ & $0-3$ & $0-3$ \\
DD & $1.85 \pm 0.52$ & $0-3$ & $1-3$ \\
SD & $1.23 \pm 0.56$ & $0-3$ & $0-3$ \\
USM & $1.05 \pm 0.59$ & $0-3$ & $0-3$ \\
HSE & $0.73 \pm 0.91$ & $0-3$ & $0-3$ \\
Poor Sleepers & $147(98.7 \%)$ & & \\
Good Sleepers & $2(1.3 \%)$ & & \\
\hline
\end{tabular}

Note: SL=Sleep Latency; SDis=Sleep Disturbances; $S S Q=$ Subjective Sleep Quality; DD=Daytime

Dysfunction; $S D=$ Sleep Duration; USM=Use of Sleeping Medication; HSE=Habitual Sleep Efficiency.

Associations between Demographic Variables, Health-Related Characteristics, Illness-Related Characteristics, Depression, and Sleep Quality

Gender, occupation, religions, and tribes were not associated with sleep quality. Among categorical data of health-related characteristics, only exercises 
was associated with sleep quality $(\mathrm{p}=0.032)$, but not smoking and alcohol consumptions. In addition, sleep quality was associated with two illness-related characteristics i.e. use of CCBs and type $2 \mathrm{DM}$ ( $p=0.035, p=0.012$, respectively). Neither hypertension stages nor hyperuricemia was associated with the sleep quality (see Table 4).

Table 4. Differences in Global Sleep Score by Demographic Variables, Health-Related Characteristics, and Illness-Related Characteristics $(n=149)$

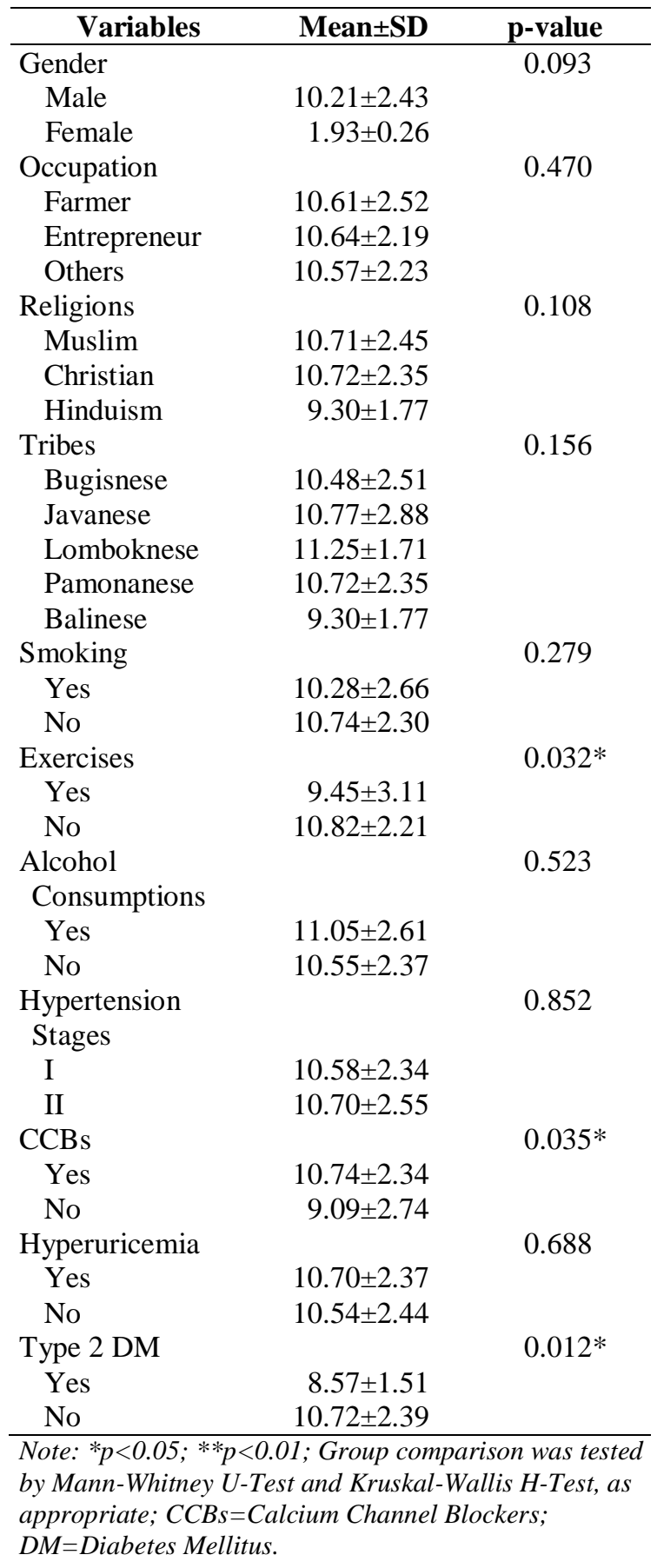

Table 5 displayed the association between depression with nocturnal sleep quality that was examined by Spearman correlation coefficients. The result indicated a significant but weak negative relationship $(r=-0.20, p<0.05)$. Depression also had similar relationship with two sleep quality components: Sleep latency $(r=-0.18, p<0.05)$ and daytime dysfunction $(\mathrm{r}=-0.25, \mathrm{p}<0.05)$. The other five components were not significantly correlated with depression, with coefficient correlations ranged from -0.13 to 0.03 ( $p>0.05$ ). Age, BMI, and duration of disease had no significant correlation with sleep quality and its components ( $r=-0.12$ to $0.70, p>0.05$ ).

\section{Table 5. The Correlations between Major Variables and Sleep Quality $(n=149)$}

\begin{tabular}{lcccl}
\hline \multicolumn{1}{c}{ Variables } & Age & BMI & Duration & Depression \\
\hline Global PSQI & -0.06 & 0.02 & 0.70 & $-0.20^{*}$ \\
SL & -0.00 & 0.02 & 0.08 & $-0.18^{*}$ \\
SDis & -0.12 & 0.04 & 0.04 & -0.13 \\
SSQ & -0.01 & 0.14 & 0.04 & -0.07 \\
DD & -0.03 & -0.04 & 0.05 & $-0.25 * *$ \\
SD & -0.03 & 0.01 & 0.04 & -0.12 \\
USM & -0.01 & 0.01 & -0.03 & 0.03 \\
HSE & 0.04 & -0.05 & 0.08 & -0.08 \\
\hline Note: *p<0.05; ** $p<0.01$ level $(2-$ tailed); Coefficient correlation \\
and p-values were calculated by Spearman Correlation; \\
SL=Sleep Latency; SDis=Sleep Disturbances; SSQ=Subjective \\
Sleep Quality; DD=Daytime Dysfunction; SD=Sleep Duration; \\
USM=Use of Sleep Medication; HSE=Habitual Sleep Efficiency; \\
BMI=Body Mass Index, Duration=Duration of Disease.
\end{tabular}

\section{Determinants of Self-Reported Sleep Quality}

Overall, there were four variables, namely exercises, use of CCBs, type $2 \mathrm{DM}$, and depression, were significantly different to global sleep score. Then, these variables were involved into multiple regression analysis to determine significant sleep quality variables. Results revealed that, among these four variables, two were identified as statistically significant determinants: Exercises and type 2 DM. Together, all these variables accounted for $11.4 \%$ of sleep quality variance (see Table 6). 
Table 6. Multiple Regression Model of Determinants on Self-Reported Sleep Quality $(n=149)$

\begin{tabular}{|c|c|c|c|c|c|}
\hline Predictors & B & SE & $\mathbf{t}$ & $\mathbf{R}^{2}$ & $\begin{array}{c}\mathbf{R}^{2} \\
\text { Chg. }\end{array}$ \\
\hline $\begin{array}{l}\text { Model } 1 \\
\text { (Constant) }\end{array}$ & 10.82 & 0.21 & & & \\
\hline Exercises & -1.36 & 0.54 & $-2.51 *$ & 4.1 & 4.1 \\
\hline \multicolumn{6}{|l|}{ Model 2} \\
\hline (Constant) & 9.72 & 0.73 & & & \\
\hline Exercises & -1.21 & 0.54 & $-2.24 *$ & 9.6 & 5.5 \\
\hline $\mathrm{CCBs}$ & 1.27 & 0.73 & 1.73 & & \\
\hline Type 2 DM & -2.06 & 0.89 & $-2.31^{*}$ & & \\
\hline \multicolumn{6}{|l|}{ Model 3} \\
\hline (Constant) & 11.09 & 1.09 & & & \\
\hline Exercises & -1.12 & 0.54 & $-2.08^{*}$ & 11.4 & 1.8 \\
\hline CCBs & 1.23 & 0.73 & 1.68 & & \\
\hline Type 2 DM & -2.15 & 0.89 & $-2.42 *$ & & \\
\hline Depression & -0.12 & 0.07 & -1.69 & & \\
\hline
\end{tabular}

\section{Discussions}

Poor sleep quality occurred among $98.7 \%$ of the study participants. The significant determinants of sleep quality were exercises and type 2 DM. There was a statistically significant difference in sleep quality between the CCBs and non-CCBs groups. However, it was not an important determinant of sleep quality. Depression had a correlation with sleep quality, but was not a determinant. No significant differences in sleep quality were seen in demographic variables including age, gender, occupation, religions, and tribes; health-related characteristics including smoking status, BMI, and alcohol consumption; illness-related characteristics including hypertension stages, diagnosis duration, and hyperuricemia.

The prevalence of poor sleep quality $(98.7 \%)$ was comparable to the Sakinah, Kosasih, and Sari (2018) study of 79 hypertensive patients $(94.6 \%)$. It is much higher than study by $\mathrm{Lu}, \mathrm{Chen}, \mathrm{Wu}$, Chen, and $\mathrm{Hu}$ (2015) among 4144 adult Chinese males with hypertension (15.3\%) and Hanus et al. (2015) study with 280 hypertensive participants in Brazil $(55.7 \%)$. In recent years, sleep problems and prevalence of hypertension were increased. Studies revealed association between subjective sleep quality and hypertension, including those with high risk (Bruno et al., 2013; Lo et al., 2018). Li et al. (2017) suggested hypertensive patients should have a better sleep condition, as it can contribute to improve the blood pressure.

Regarding the components of sleep quality, participants gave the highest mean score to sleep latency (duration needed to initiate sleep), which is consistent with the findings reported by Chen, Clark, Tsai, and Lin (2010) in heart failure patients, where hypertension was the major comorbid in their study. However, in Zhao, Fu, Ren, and Luo (2018) study, subjective sleep quality score had the highest score in different groups of blood pressure rhythm among Chinese patients with hypertension. A common sleep problem, insomnia, which has symptom of trouble initiating sleep (poor latency of sleep), through the mediation of hypertension is associated with an increased risk of cardiovascular diseases (Sofi et al., 2014). The co-existing between insomnia and hypertension may be explained by the excessive activity of sympathetic nervous system and hypothalamic-pituitary-adrenal axis or HPA, marked by the overproduction of catecholamine, cortisol, and adrenocorticotropic hormones (Riemann et al., 2010).

Mild to moderate depression was prevalent in $77.9 \%$ of the participants. The prevalence of depression in this study, however, were higher than reported in Hamrah et al. (2018) study with 234 hypertensive outpatients $(58.1 \%)$. In this study, depression was not a determinant of sleep quality, but it had negative and weak correlation with global sleep score, sleep latency, and daytime dysfunction. This finding is incongruent with previous study who found sleep quality was positively correlated with depression in hypertensive patients. Sleep quality can be improved through psychological intervention and relaxation in depressed patients with hypertension (Ma \& Li, 2017). In addition, reducing the blood pressure in hypertensive patients can be done through a combination of improving sleep and controlling psychological problem such as depression (Li et al., 2017).

Exercises was the only health-related characteristic had significant difference on sleep quality and was found as an important determinant. Those who did regular exercise had lower score of global sleep score. Bakker, Sui, Brellenthin, and Lee (2018) stated that exercise is included in the front line to treat patients with hypertension. During the data collection for this study, we found that majority of rural participants said regular exercise was not a common practice because they viewed it as a part of their daily physical activity during working such as walking or farming. The participants' understanding regarding exercise and physical activity in this study was similar with a study by Oelke et al. (2015) in Zambia. The benefit of exercise on sleep are still unclear, but may related to energy efficiency (Myllymaki et al., 2011). Fairbrother et al. (2014) hypothesized that better sleep quality can be resulted by hormonal effects, particularly leptin, which appears above it usual level in deep sleep period and 
taking role as regulator of energy conservation or consumption.

Except for the use of CCBs and type $2 \mathrm{DM}$, the other illness-related characteristics such as stages of hypertension, hyperuricemia, and duration of disease did not show significant correlation/differences on sleep quality. Participants who took prescribed CCBs (primarily amlodipine) were good sleepers. However, CCBs may have a negative effect on sleep, in particular significantly reducing its duration among hypertensive patients with obstructive sleep apnea (OSA). This finding needs further studies to clarify the mechanisms (Nerbass, Pedrosa, Genta, Drager, \& Lorenzi-Filho, 2011).

Type 2 DM was a determinant of sleep quality in this study. Those with type 2 DM had a better sleep quality. An older study by Fiorentini, Valente, Perciaccante, and Tubani (2007) stated that type 2 DM was associated with sleep quality in hypertensive patients, although the pathogenetic process remained unclear. Some potential mechanisms such as the hyperactivity of HPA and sympathetic nervous system were suspected as the mediator of the relationship among sleep, hypertension, and type $2 \mathrm{DM}$. The finding on this study may related to glycemic control, as it is the corner stone in DM management (Surani, Brito, Surani, \& Ghamande, 2015). Zhu, Li, Wang, and Yu (2014) found that glycemic control had relationship with sleep quality. In their study, participants who controlled their glycemic control adequately had significant lower score than those who did not.

There were some limitations in this study. The use of accidental sampling and cross-sectional approach restricted the generalizability of the findings, because it only highlights correlations but not a cause and effect relationship (Kellar \& Kelvin, 2012). Because the data collection were only taken from two public health care areas located in Central Sulawesi, the study findings may not portrayed the situations of the patients who were living in other areas of the province or Indonesia in general. Future research should recruited more participants with higher degree of hypertension in larger area to better understand the effect of disease on sleep quality. Potential of response bias may happen, due to the findings only obtained from subjective data. Moreover, the lack of objective measures inhibited to collect more comprehensive data about variables in this study.

\section{Conclusions}

Mild to moderate depression and poor sleep quality were prevalent in patients with hypertension. Sleep latency was the main problem of sleep components among participants. Any changes in mental health and pattern of sleep should be identified early. Some factors were found significantly associated with sleep quality such as exercises, use of CCBs, and type 2 DM. Depression was correlated, but not a determinant of sleep quality. Only exercises and type $2 \mathrm{DM}$ were found as statistically significant determinants. Thus, it is important to arrange patients' regular exercise and controlling co-existing disease particularly type 2 DM. Nurses can help patients in adjusting patients' exercise based on tolerance to activities and energy levels, increasing adherence to take medication, and supplying adequate information about good sleep, such as sleep hygiene. These findings enhance knowledge with insights into the determinants of sleep quality in hypertensive patients and bring information on management/caring strategies of disease. Further studies on other possible factors such as stress, nutrition, and daytime sleepiness are necessary.

\section{Conflict of interest}

The authors declare no conflict of interest associated with this manuscript.

\section{Acknowledgement}

The authors are grateful for MAPI Research Trust (Lyon, France), as official license distributor, for facilitating the access to PSQI questionnaire in Bahasa Indonesia version. The contributions of all of the study participants and interviewers are gratefully acknowledged. This study received no specific grant from any funding.

\section{References}

Ademola, A., Boima, V., Odusola, A., Agyekum, F., Nwafor, C., \& Salako, B. (2019). Prevalence and determinants of depression among patients with hypertension: A cross-sectional comparison study in Ghana and Nigeria. Nigerian Journal of Clinical Practice, 22(4), 558-565. doi:10.4103/njcp.njcp_351_18

Allabadi, H., Alkaiyat, A., Alkhayyat, A., Hammoudi, A., Odeh, H., Shtayeh, J., . . . Probst-Hensch, N. (2019). Depression and anxiety symptoms in cardiac patients: A cross-sectional hospitalbased study in a Palestinian population. BMC Public Health, 19(1), 232. doi:10.1186/s12889-019-6561-3

Bakker, E. A., Sui, X., Brellenthin, A. G., \& Lee, D. C. (2018). Physical activity and fitness for the prevention of hypertension. Current Opinion in 
Cardiology, 33(4), 394-401. doi:10.1097/hco.0000000000000526

Bruno, R. M., Palagini, L., Gemignani, A., Virdis, A., Di Giulio, A., Ghiadoni, L., . . . Taddei, S. (2013). Poor sleep quality and resistant hypertension. Sleep Medicine, 14(11), 1157-1163. doi:10.1016/j.sleep.2013.04.020

Buysse, D. J., Reynolds, C. F., Monk, T. H., Berman, S. R., \& Kupfer, D. J. (1989). The Pittsburgh sleep quality index: A new instrument for psychiatric practice and research. Psychiatry Research, 28(2), 193-213. doi:10.1016/01651781(89)90047-4

Centers for Disease Control and Prevention. (2016). High blood pressure fact sheet. Retrieved from https://www.cdc.gov/dhdsp/data_statisti cs/fact_sheets/fs_bloodpressure.htm\#tar getText=About $\% 2075 \% 20$ million $\% 20 \mathrm{~A}$ merican $\% 20$ adults, $1 \% 20$ in $\% 20$ every $\% 2$ 03\%20adults.\&targetText=About $\% 201$ $\% 20$ in $\% 203 \% 20$ American,the\%20high $\%$ 20blood\%20pressure\%20range.

Chaput, J. P., McNeil, J., Despres, J. P., Bouchard, C., \& Tremblay, A. (2013). Short sleep duration as a risk factor for the development of the metabolic syndrome in adults. Preventive Medicine, $\quad$ 57(6), $\quad 872-877$. doi:10.1016/j.ypmed.2013.09.022

Chen, H. M., Clark, A. P., Tsai, L. M., \& Lin, C. C. (2010). Self-reported health-related quality of life and sleep disturbances in Taiwanese people with heart failure. Journal of Cardiovascular Nursing, 25(6), 503-513. doi:10.1097/JCN.0b013e3181e15c37

Cohen, J. (1988). Statistical power analysis for the behavioral sciences (2nd ed.). United States of America: Lawrence Erlbaum Associates.

Damanik, E. D. (2011). The measurement of reliability, validity, items analysis and normative data of depression anxiety stress scale (DASS). Retrieved from http://www2.psy.unsw.edu.au/groups/D ASS/Indonesian/Damanik\%20Indonesia $\mathrm{n} \% 20$ translation\%20$\% 20$ Reliability.doc

Fairbrother, K., Cartner, B., Alley, J. R., Curry, C. D., Dickinson, D. L., Morris, D. M., \& Collier, S. R. (2014). Effects of exercise timing on sleep architecture and nocturnal blood pressure in prehypertensives. Vascular Health and Risk Management, 10, 691-698. doi:10.2147/VHRM.S73688
Faul, F., Erdfelder, E., Buchner, A., \& Lang, A.G. (2009). Statistical power analyses using G*Power 3.1: Tests for correlation and regression analyses. Behavior Research Methods, 41(4), 1149-1160. doi:10.3758/brm.41.4.1149

Faul, F., Erdfelder, E., Lang, A.-G., \& Buchner, A. (2007). G*Power 3: A flexible statistical power analysis program for the social, behavioral, and biomedical sciences. Behavior Research Methods, 39(2),

175-191. doi:10.3758/BF03193146

Fiorentini, A., Valente, R., Perciaccante, A., \& Tubani, L. (2007). Sleep's quality disorders in patients with hypertension and type 2 diabetes mellitus. International Journal of Cardiology, 114(2), E50-E52. doi:10.1016/j.ijcard.2006.07.213

Göder, R., Hinrichsen, I., Seeck-Hirschner, M., Pfeiffer, R., Weinhold, S. L., Baier, P. C., . . S Schulz-DuBois, C. (2016). Sleep at baseline and after electroconvulsive therapy in patients with major depression. Psychiatry Research, 246, 683-687.

doi:10.1016/j.psychres.2016.10.064

Hamrah, M. S., Hamrah, M. H., Ishii, H., Suzuki, S., Hamrah, M. H., Hamrah, A. E., . . . Hamrah, M. H. (2018). Anxiety and depression among hypertensive outpatients in Afghanistan: A crosssectional study in Andkhoy City. International Journal of Hypertension, 2018, 1-8. doi:10.1155/2018/8560835

Hanus, J. S., Amboni, G., Rosa, M. I., Ceretta, L. B., \& Tuon, L. (2015). The quality and characteristics of sleep of hypertensive patients. Revista da Escola de Enfermagem da USP, 49(4), 596-602. doi:10.1590/s0080623420150000400009

Hsu, H.-C., Chen, N.-H., Ho, W. J., \& Lin, M.H. (2018). Factors associated with undiagnosed obstructive sleep apnoea among hypertensive patients: A multisite cross-sectional survey study in Taiwan. Journal of Clinical Nursing, 27(9-10), 1901-1912. doi:10.1111/jocn.14366

Kara, B., \& Tenekeci, E. G. (2017). Sleep quality and associated factors in older turkish adults with hypertension: A pilot study. Journal of Transcultural Nursing, 28(3), 296-305. doi:10.1177/1043659615623330

Kellar, S. B. P., \& Kelvin, E. A. (2012). Munro's statistical methods for health care 
research (6th ed.). Philadelphia, PA: Wolters Kluwer Health/Lippincott Williams \& Wilkins.

Kobayashi, D., Takahashi, O., Deshpande, G. A., Shimbo, T., \& Fukui, T. (2011). Relation between metabolic syndrome and sleep duration in Japan: A large scale cross-sectional study. Internal Medicine, 50(2), 103-107. doi:10.2169/internalmedicine.50.4317

Lainsamputty, F., \& Chen, H.-M. (2018). The correlation between fatigue and sleep quality among patients with heart failure. NurseLine Journal, 3(2), 100114. doi:10.19184/nlj.v3i2.8580

Li, J., Shi, L., Li, S., Xu, L., Qin, W., \& Wang, H. (2017). Urban-rural disparities in hypertension prevalence, detection, and medication use among Chinese Adults from 1993 to 2011. International Journal for Equity in Health, 16(1), 5050. doi:10.1186/s12939-017-0545-7

Li, L., Wu, C., Gan, Y., Qu, X., \& Lu, Z. (2016). Insomnia and the risk of depression: A meta-analysis of prospective cohort studies. BMC Psychiatry, 16(1), 375. doi:10.1186/s12888-016-1075-3

Li, Y., Yang, Y., Li, Q., Yang, X., Wang, Y., Ku, W. L., \& Li, H. (2017). The impact of the improvement of insomnia on blood pressure in hypertensive patients. Journal of Sleep Research, 26(1), 105114. doi:10.1111/jsr.12411

Lo, K., Woo, B., Wong, M., \& Tam, W. (2018). Subjective sleep quality, blood pressure, and hypertension: a meta-analysis. The Journal of Clinical Hypertension, 20(3), 592-605. doi:10.1111/jch.13220

Lovibond, P. F., \& Lovibond, S. H. (1995). The structure of negative emotional states: Comparison of the Depression Anxiety Stress Scales (DASS) with the Beck Depression and Anxiety Inventories. Behaviour Research and Therapy, $33(3), \quad 335-343$. doi:10.1016/00057967(94)00075-U

Lu, K., Chen, J., Wu, S., Chen, J., \& Hu, D. (2015). Interaction of sleep duration and sleep quality on hypertension prevalence in adult Chinese males. Journal of Epidemiology, 25(6), 415422. doi:10.2188/jea.JE20140139

Ma, L., \& Li, Y. (2017). The effect of depression on sleep quality and the circadian rhythm of ambulatory blood pressure in older patients with hypertension. Journal of Clinical Neuroscience, 39, 49-52. doi:10.1016/j.jocn.2017.02.039
Ma, L., Tang, Z., Sun, F., Diao, L., Li, Y., Wang, J., . . Q Qian, Y. (2015). Risk factors for depression among elderly subjects with hypertension living at home in China. International Journal of Clinical and Experimental Medicine, 8(2), 29232928.

Mahmood, S., Hassan, S. Z., Tabraze, M., Khan, M. O., Javed, I., Ahmed, A., . . . Fatima, K. (2017). Prevalence and predictors of depression amongst hypertensive individuals in Karachi, Pakistan. Cureus, 9(6), e1397-e1397. doi:10.7759/cureus. 1397

Meng, L., Chen, D., Yang, Y., Zheng, Y., \& Hui, R. (2012). Depression increases the risk of hypertension incidence: A metaanalysis of prospective cohort studies. Journal of Hypertension, 30(5), 842851. doi:10.1097/HJH.0b013e32835080b7

Ministry of Health Republic of Indonesia. (2019). Hipertensi penyakit paling banyak diidap masyarakat. Retrieved from

http://www.depkes.go.id/article/print/19 051700002/hipertensi-penyakit-palingbanyak-diidap-masyarakat.html

Myllymaki, T., Kyrolainen, H., Savolainen, K., Hokka, L., Jakonen, R., Juuti, T., . . . Rusko, H. (2011). Effects of vigorous late-night exercise on sleep quality and cardiac autonomic activity. Journal of Sleep Research, 20(1 Pt 2), 146-153. doi:10.1111/j.1365-2869.2010.00874.X

Nerbass, F. B., Pedrosa, R. P., Genta, P. R., Drager, L. F., \& Lorenzi-Filho, G. (2011). Calcium channel blockers are independently associated with short sleep duration in hypertensive patients with obstructive sleep apnea. Journal of Hypertension, 29(6), 1236-1241. doi:10.1097/HJH.0b013e3283462e8b

Nordin, R. B., Kaur, M. A., Soni, T., Por, L. K., \& Miranda, S. (2017). Construct validity and internal consistency reliability of the Malay version of the 21-item depression anxiety stress scale (Malay-DASS-21) among male outpatient clinic attendees in Johor. The Medical Journal of Malaysia, 72(5), 264-270.

Oelke, N. D., Rush, K. L., Goma, F. M., Barker, J., Marck, P., \& Pedersen, C. (2015). Understanding perceptions and practices for Zambian adults in western province at risk for hypertension: An exploratory descriptive study. Global Journal of 
Health Science, $8(2), \quad 248-259$. doi:10.5539/gjhs.v8n2p248

Polit, D. F., \& Beck, C. T. (2012). Nursing research: Generating and assessing evidence for nursing practice (9th ed.). Philadelphia, PA: Wolters Kluwer Health/Lippincott Williams \& Wilkins.

Prathibha, M., Varghese, S., \& Jincy, J. (2017). Prevalence of depression among hypertensive individuals in urban Trivandrum: A cross sectional study. International Journal of Community Medicine and Public Health, 4(6), 2156-2161. doi:10.18203/23946040.ijcmph20172194

Rani, R., Mengi, V., Gupta, R., \& Sharma, H. (2015). Hypertension and its risk factors - A cross sectional study in an urban population of a north Indian District. Public Health Research, 5(3), 67-72. doi:10.5923/j.phr.20150503.01

Riemann, D., Spiegelhalder, K., Feige, B., Voderholzer, U., Berger, M., Perlis, M., \& Nissen, C. (2010). The hyperarousal model of insomnia: A review of the concept and its evidence. Sleep Medicine Reviews, 14(1), 19-31. doi:10.1016/j.smrv.2009.04.002

Sakinah, P. R., Kosasih, C. E., \& Sari, E. A. (2018). Gambaran kualitas tidur pada penderita hipertensi. Media Kesehatan Politeknik Kesehatan Makassar, 13(2), 46-52. doi:10.32382/medkes.v13i2.663

Sofi, F., Cesari, F., Casini, A., Macchi, C., Abbate, R., \& Gensini, G. F. (2014). Insomnia and risk of cardiovascular disease: A meta-analysis. European Journal of Preventive Cardiology, 21(1), 57-64. doi:10.1177/2047487312460020

Surani, S., Brito, V., Surani, A., \& Ghamande, S. (2015). Effect of diabetes mellitus on sleep quality. World Journal of Diabetes, $\quad$ 6(6), 868-873. doi:10.4239/wjd.v6.i6.868

World Health Organization. (2011). Global status report on noncommunicable diseases 2010. Geneva, Switzerland Retrieved from https://www.who.int/nmh/publications/n cd_report_full_en.pdf.

World Health Organization. (2019). Hypertension. Retrieved from https://www.who.int/news-room/factsheets/detail/hypertension\#targetText=An\%20estimated $\% 201.13$ $\% 20$ billion $\% 20$ people,cause $\% 20$ of $\% 20$ premature $\% 20$ death $\% 20$ worldwide.
Xu, X., Rao, Y., Shi, Z., Liu, L., Chen, C., \& Zhao, Y. (2016). Hypertension impact on health-related quality of life: A cross-sectional survey among middleaged adults in Chongqing, China. International Journal of Hypertension, 2016. doi:10.1155/2016/7404957

Xue, J., Chen, S., Bogner, H. R., Tang, W., Li, L., \& Conwell, Y. (2017). The prevalence of depressive symptoms among older patients with hypertension in rural China. International Journal of Geriatric Psychiatry, 32(12), 14111417. doi:10.1002/gps.4628

Zhang, J.-T., Chen, K.-P., Guan, T., \& Zhang, S. (2015). Effect of aliskiren on cardiovascular outcomes in patients with prehypertension: a meta-analysis of randomized controlled trials. Drug Design, Development and Therapy, 9, 1963-1971. doi:10.2147/DDDT.S75111

Zhao, S., Fu, S., Ren, J., \& Luo, L. (2018). Poor sleep is responsible for the impaired nocturnal blood pressure dipping in elderly hypertensive: A cross-sectional study of elderly. Clinical and Experimental Hypertension, 40(6), 582588. doi:10.1080/10641963.2017.1411495

Zhu, B.-Q., Li, X.-M., Wang, D., \& Yu, X.-F. (2014). Sleep quality and its impact on glycaemic control in patients with type 2 diabetes mellitus. International Journal of Nursing Sciences, 1(3), 260265. doi:10.1016/j.ijnss.2014.05.020 